\title{
Historical Evolution and Cultural Reflection of Variety Show of Chinese Television Culture*
}

\author{
Min Luo \\ The Art Department \\ Communication University of China \\ Beijing, China 100024 \\ School of Digital Arts \\ Xi'an University of Post \& Telecommunications \\ Xi'an, China 710121
}

\author{
Qun Xie \\ The Art Department \\ Communication University of China \\ Beijing, China 100024 \\ School of Digital Arts \\ Xi'an University of Post \& Telecommunications \\ Xi'an, China 710121
}

\begin{abstract}
In recent years, Chinese television has created a trend of "Cultural Variety". Chinese Poetry Conference (the 2nd Season), Readers and Everlasting Classics have become "faddish" programs in succession. By teasing and summarizing the historical evolution of cultural variety shows in Chinese television in forty years since the reform and opening up, this paper attempts to analyze the internal logic formed in the current "cultural variety" fever, further rethinks the dilemmas faced by current cultural variety shows in inheriting the culture and spreading ideas and proposes the development principles and stand in the future.
\end{abstract}

Keywords-cultural variety shows; evolution; cultural inheritance; reflect; dilemma

\section{INTRODUCTION}

Under the broad environment of "cultural confidence" and the macro control of relevant departments, significant changes have occurred in the field of entertainment TV programs since the 18th National Congress of the Communist Party of China. "Originality, culture and public benefit" have become new keywords of entertainment TV programs. It is worth mentioning that tremendous cultural variety shows spring up like mushrooms, presenting the trend of "all flowers bloom together, and all schools of thoughts contend for attention" and building a gorgeous new landscape of Chinese television. In particular, original cultural variety shows Chinese Poetry Conference (the 2nd season), Readers (the 1st season) and Everlasting Classics have become "blockbuster" with a high audience rating, good reputation and great influence in succession and aroused heated discussion of all the people. The upsurge of "cultural variety" on TV advanced irresistibly.

Presently, the word cultural variety show has been widely used by mass media and formed a conventional concept. What is cultural variety show on earth? First of all, we need to explicitly define its concept.

The word "culture" has many definitions and the universal meaning is "culture refers to a life style and related symbol

*This paper is the phased research fruit of Humanities and Social Sciences special projects of Research on the Expression and Communication of Chinese Traditional Cultural Resources under the Background of Cultura Power of Shanxi Provincial Education Department (2018) systems and values formed by it". [1] Under the context of daily communication, culture has also embodied relatively high-level culture, experience, aesthetic standards and academic levels. Variety show means "integrating all or several music, song and dance, drama and skit, fragments of traditional Chinese opera, guessing game, funny stories and wushu games and freely and flexibly arranging and combing according to the demands of contents to meet the aesthetic needs of audiences via the effects of light and color, temporal and spatial variation and unique modeling on television." [2] To sum up, cultural variety shows are variety shows that guide us toward certain life style, symbol system and values and have a relatively high cultural connotation and aesthetic standards. The cultural variety shows inspected in this paper all base on this concept.

In January 1979, China's first television cultural program the Foreign Cultures started to broadcast, marking China's television art becomes mature and opening nearly forty years of evolution of television variety shows (including cultural variety).

\section{Historical EVOLUTION OF CULTURAL VARIETY SHOWs}

Just as Hegel says, "Every artistic work has its own era and nation and has special environment and depends on special, historical and other ideas and purposes."[3] In different historical periods and cultural contexts, the form of variety shows has evolved unceasingly. According to the dominant types of variety at different periods, this paper has divided it into four periods, namely "Grand Variety Stage", "Game or Puzzle", "Thriving Reality Show" [4] and "New Mainstream Variety" [5]. Cultural variety show is one of its subtypes. Its evolution vein and the field evolution of all the variety shows echo and have difference.

\section{A. The Period of "Grand Variety Stage" (1980s to the Late 1990s): Cultural Variety Under Elite Culture}

The 1980s is an important period of the flourish of television culture after the stagnation during the Cultural Revolution. The enlightenment thoughts and modern ideas of elite intellectuals have been extensively spreaded via many artistic forms such as literature, movie and televisions. The 
Spring Festival Gala Evening in 1983 is the television cultural work appeared under elite culture and has a relatively high cultural taste. The Spring Festival Gala Evening has integrated guessing game, Peking Opera, crosstalk, acrobatics and singing and presented the artistic characteristics that combine aesthetic nature, knowledge, idea and art. In this period, evening parties of television variety represented by the Spring Festival Gala Evening begin to proactively integrate elements of the traditional culture and elite culture in the creation, having directly influencing the creation of subsequent variety shows. For example, the two top-level variety shows Super Variety Show and Zhengda Variety Show have taken the traditional cultural and artistic contents as an important component.

In this period, Quyuan Zatan aims at "carrying forward the traditional Chinese culture and showing treasures of national art"; Dong Xi Nan Bei Zhong introduces cultural customs of various regions; Revolving Stage integrates the quintessence of song, dance and music, carries forward national culture and popularizes high art; the comprehensive cultural "magazine" program Arts View integrates crosstalk, witty skits, exclusive interview on masters, music, song and dance. All of them conform to the aesthetic taste of grandiose narration, cultural enlightenment and high art highly praised by the mainstream elites at that time.

\section{B. The Period of "Game Or Puzzle" (the Late 1990s to 2004). Cultural Variety Eroded by the Mass Culture}

With the reform of the economic system and the transformation of social structure from 1990s to the new century, the ideological trend of consumerism and mass culture rises, suppressing the elite discourse that dominated in the past. Under the trend of marketization and popularization, most entertainment programs on television in this period begin "game playing and entertainment" and pursued the maximization of entertainment effect. "Culture" is excluded to the opposite side of entertainment and only enjoyed by a small number of people.

In this period, some cultural variety shows pursue the compromise with the mass culture. The programs focusing on game and entertainment represented by Happy Camp make an utmost effort to pursue "the vortex of happiness" to dispel television culture; puzzle shows represented by Happy Dictionary and Lucky 52 take knowledge as the subject and popularize knowledge through guessing game regarding knowledge shown by audio-visual technique of television. However, people do not focus on knowledge in these programs but the rivalry and suspense brought by the guessing. Other cultural variety shows are relegated to the poetic space that is unpopular among the masses. For example, TV Poetry and Prose sticks to cultural quality and pursues the purification of soul and spiritual enlightenment, but it fails to get rid of the situation of being too high to be popular when the entertainment is popular among people.

\section{The Period of "Thriving Reality Show" (2004 to 2012). Cultural Reality Under the Intercourse of Pluralistic Cultures}

The influence of mass culture has been still extensive since the new century, but it cannot do without the guidance and containment of mainstream culture. At the meantime, the correction and criticism from elite culture is not absent. Three cultures are continuously seeking dynamic balance and interweave with each other. Super Girl soars splendidly in 2004, implying the variety shows in China enter the period of "Reality Show". Talent shows have created the situation of "all-people participation" and rating miracle via keywords such as "mass-election", "zero threshold", "PK", "civilian" and "superstar creation" and the slogan of "singing freely and singing loudly". Since then, all kinds of reality shows become prevailing in succession, presenting the landscape of "reality", "people" and "show".

Cultural variety shows in this period seek creation space in the dialogue and interaction of mass culture, dominant culture and elite culture, and the cultural quality is uneven. As a "talent show" program that has a relatively long history, CCTV Young Singers Grand Prix still persists in the original intention of "carry forward national art, popularizing music knowledge, discovering and promoting vocal music talents", having become the fresh air in the fever of talent show; the talent show China Red Song Show on JXTV is also different from the popular talent shows and focuses on "the lofty combination of fashion and classics; while the program Characters in A Dream in Red Mansions on BTV to select actors for the new edition A Dream in Red Mansions could integrate the great and profound traditional Chinese culture and art in A Dream in Red Mansion, but the effect shown by the program is unsatisfactory, putting "show" above "culture"; programs that are not talent show such as Happy China Tour make efforts to present regional culture and city enchantment via fashion packing; variety shows such as Treasure Appraisal and The Collection declare they aim at diffusing professional knowledge, but creating the so-called "vulgar taste" even "stunt", such as the hammer used by the host Wang Gang to smash counterfeits.

\section{The Period of "New Mainstream Variety" (2013 Now): \\ Cultural Variety Under the Observation of "Cultural Confidence"}

"New Mainstream Variety" derives from the concept of "new mainstream movie or television" proposed by academic circle in recent years. These variety shows "respond to the national cultural strategy and carry forward our traditional values and excellent culture in artistic forms" [7]. The expression is close to the mainstream values and caters to the public. In essence, it evens elite culture and mass culture under the dominance of mainstream culture. Since the 18th National Congress of the Communist Party of China, under the grand strategy of "powerful cultural country", the important mission of the mainstream media in the new era is to base on cultural diffusion, build Chinese cultural styles and manifest cultural confidence.

In this period, cultural variety shows are considerable on quality and quantity. Since the program Chinese Spelling Hero 
"reflecting the beauty of Chinese" on HNTV in 2013 opens the new idea of deeply integrating variety and culture, television creators have turned their eyes to the great and profound traditional Chinese cultural resources. The "Conference" series on CCTV have deeply integrated traditional culture such as Chinese characters, idioms, riddles and poetries with variety entertainment and successfully created brands of television cultural variety. Programs such as Super Brain and Inheritor have created "cultural wonder exhibition" via audio-visual aids of television. The program Everlasting Classics has broken the limitation of cultural variety subjects through the innovative thinking of "poetry and song" and opened new expression ways of cultural variety. At present, television platforms are energetically launched cultural variety shows. The subjects are extensive and have involved traditional cultural samples like Chinese characters, idioms, riddles, poetries, letters, folk songs, literary quotations and folk customs, and the positioning is different. Cultural variety shows have become the "theme" in the period of "New Mainstream Variety".

\section{Cultural REFLECTION ON THE CUltural VARIETY SHOWS AT PRESENT}

According to the diachronic review on the evolution of forms of cultural variety shows, the benign development trend of the current cultural variety shows is extremely difficult and requires the combined action of social and cultural trends, macro policy and survival logic of media. It has also embodied the improvement and optimization of the overall environment of Chinese television culture. Television creators have finally found "Chinese characteristics" of television entertainment and returned to the cultural self-consciousness and cultural confidence of China. To avoid historical degradation, further improve the Chinese television cultural environment, realize sustainable development of cultural variety shows as well as better inherit culture and diffuse ideas, it is necessary to conduct profound cultural reflection and seek out the development dilemma of current cultural variety shows and the countermeasures.

The review on cultural variety shows on television from the cultural perspective shows it is in essence the high enrichment of classic symbols, classic cultural situation and classics and "fast food" of modern elite culture and traditional Chinese culture. Although cultural variety shows play the role of correcting and guiding the vulgar consumption tendency of "Amusing to Death", we must look through the dilemma faced by it on cultural inheritance and dissemination of ideas via the booming scene of "all flowers bloom together" of cultural variety. This paper will analyze from two dimensions, external (environment) and internal (program):

\section{A. Globalization and the Silence of Chinese Television Culture}

Globalization is "a complex link of modern world and the characteristic of interconnected and interdependent modern social life, especially the interconnected and interdependent network system with rapid development and ceaseless compression" [7]. It is an inevitable trend in the world's development process. Globalization has brought economic integration, which is accompanied by the collision of cultures around the world. In this process, the voice of weak culture is often covered by that of strong culture. They are in the "aphasia" state in international communication because of failing to win the speaking right.

"Aphasia" is also the practical problem faced by Chinese television culture. The aphasia of Chinese television culture shows Chinese television cannot accurately deliver Chinese cultural values and connotation but often "respect foreign things, regard foreign things as beauty, tolerate foreign things and regard the awards obtained at abroad as the highest pursuit..." [8], failing to establish a scientific evaluation system. Meaningless emptiness and cultural phantom are inundated.

In the field of television variety, we have scrambled for foreign "pattern" for a long period of time, created hollow sensory stimuli and meaningless signifier even behaved with wrong values in programs to attract audiences, such as judges 'quarrel, the declaration of money worship and hype of love affairs. It undoubtedly has produced negative impact on the development of Chinese television variety shows. Currently, some original cultural variety shows are popular among audiences because of the improvement of cultural tastes and production standards, but they only make a difference at home and have not found effective ways of establishing international discourse and route of transmission. To "tell Chinese stories and diffuse Chinese voice" and let the traditional excellent Chinese culture "go out", cultural variety shows on television must establish mature and stable television cultural value systems and international communication systems, which need long-term practice and exploration.

\section{B. Paradox of Cultural Absence and Cultural Presence}

According to the review on the development vein of cultural variety shows, it is evident that cultural absence, panentertainment, loftiness dispelling, planarity and depth absence have become keywords of Chinese television in the period that mass culture and consumerism are prevailing. Compared with the period before, the current Chinese variety shows on television are cultural presence evidently. Does cultural presence mean they can inherit culture and diffuse ideas? Cultural presence many improve the cultural ethos of entertainment programs, but we cannot easily draw conclusion on whether it can inherit culture and diffuse ideas.

Firstly, the logic of market dispels cultural thoughts. Culture often needs compromise under the market logic. The market logic of cultural variety shows means pursing audience rating. In the pursuit of high audience rating, we must consider the masses, visualization, interestingness, emotional topics and celebrities and conduct second creation of cultural contents through television-based means. In the process of first choice and second creation, excellent cultures that have rich connotation, profound thoughts and far-reaching meaning but are unsuitable for television performance are shielded. "Culture" presented by the second creation is processed by television and adapts to audio-visual acceptance way of television. It is fragmented and de-deepened even deconstructed by entertainment. Culture with elite color is comprehensively brought by entertainment programs in the context of mass culture to fill up the cultural significance and cultural imagination lacked in today's society. In reality, it has 
been reduced to consumer goods under the market logic of television.

Secondly, visual culture extrudes character culture. Text in the style of traditional characters is expressed via the technique of television variety. The conversion from character culture to visual culture has dispelled the charm of characters and led to visual consumption. For example, to enhance the viewing effect, some programs of reading have translated writings in classical Chinese into writings in the vernacular and shown contents of characters via actors' performance to bring audiences sensory pleasures. However, the profound connotation of traditional culture is converted into activity of cultural performance in this process, leading to the absence of texts' depth and the dispelling of implication of characters by visual images. The view of audiences' eyes has replaced the thinking of brain. The strong visual culture has weakened the meaning expression and value construction of traditional culture and elite culture in variety shows.

Under the joint forces of market forces and consumption culture of television media, the traditional culture has been transformed into a series of cultural symbols with strong visibility and conforming to the market logic. "Culture" becomes the best carrier to meet audiences' psychology of worshiping elite culture and has to some extent accorded with audiences' psychology of expecting to gain knowledge in the atmosphere of "teaching through lively activities". However, it at the meantime has weakened the functions of cultural variety shows in inheriting culture and diffusing thoughts.

\section{CONCLUSION}

Chinese cultural variety shows actually have welcomed the advantaged development opportunities after experiencing a long-term exploration period. Some cultural variety shows have obtained double harvest of market benefits and social benefits by virtue of a relatively high cultural taste and ideological connotation. Excellent Chinese culture and elite culture have also attracted people's attention again by virtue of the "grand stage" of variety shows and aroused the "national culture fever" in the whole society. However, it is worth considering whether can cultural variety shows make visual culture and character culture realize meaning improvement in the inter-textual mechanism, whether can it construct Chinese cultural values and manifest Chinese aesthetic spirit in order to better inherit culture and diffuse thoughts and better let excellent Chinese culture "go out" via cultural variety shows?

General Secretary Xi observes, "Hope you stick to cultural confidence and inspire national spirit through literature and art... create excellent works with distinct national characteristics and individuality, deeply understand the extensive and profound Chinese culture with high cultural confidence."[9]It is the guiding principle and stand of the creation of cultural variety shows in China. We must adhere to cultural confidence. The extensive and profound Chinese culture has provided diversified and inexhaustible resources for variety shows on television. We should not be confined to the superficial cultural interpretation of symbols and "cultural performances" and the stereotyped image opposite to cultural logic and market logic. Instead, we must deeply and comprehensively interpret Chinese cultural discourse and present the breadth, height and depth of Chinese culture and create excellent works with national characters and universal values.

\section{REFERENCES}

[1] [Britain]Elaine Baldwin, et al. Introducing Cultural Studies, translated by Tao Dongfeng, et al. Higher Education Press, 2005, page 4-8

[2] Editors-in-chief Zhong Yibing, Huang Wangnan, Development History of Chinese TV Art, Zhejiang People's Publishing House, 1994, page 514

[3] [Germany]Hegel, Aesthetics (Volume 1), Commercial Press, edition 1979, page 19

[4] Liu Jun, Hu Zhifeng, "Blowout" of Pluralistic Styles: New Landscapes Produced by Contents of Chinese TV Variety Shows, the $2^{\text {nd }}$ issue in 2015

[5] Gai Qi. Concepts, Forms and Discourses: Triple Inspections on TV Cultural Variety Show, TV Research, the $5^{\text {th }}$ issue in 2018

[6] Chen Xuguang, China's New Mainstream Event Movie: Interpretation and Construction, Hundred Schools in Arts, the $5^{\text {th }}$ issue in 2017

[7] [Britain] John Tomlinson; translated by Guo Yingjian, Globalization and Culture, Nanjing: Nanjing University Press, 2002, page 2

[8] Publicity Department of the Communist Party of China, Reader on Learning General Secretary Xi Jinping's Important Speech at the Symposium on Literary and Artistic Work, Beijing: Learning Press, 2015, page 28

[9] Xi Jinping: Speech at the Opening Ceremony of the 10th National Congress of China Federation of Literary and Art Circles and the 9th National Congress of Chinese Writers Association, xinhuanet, http://news.xinhuanet.com, Nov.30,2016 